\title{
EXPLOITATION AND CONSERVATION OF SEALS IN SOUTH GEORGIA
}

\author{
By W. Nigel Bonner \\ Biologist, South Georgia
}

Almost from the date of their discovery by Captain Cook in 1775 the seal stocks of South Georgia have formed the basis of a lucrative, though initially sporadic, industry.

South Georgia lies between 54 degrees and 55 degrees South and between 36 degrees and 38 degrees West. Despite its low latitude it has an antarctic climate, being south of the Antaretic Convergence at all scasons of the year. True sea ice is probably never formed on any of its coasts though enormous quantities of brash ice from the many glaciers may frequently obstruct access to certain beaches. Meteorological observations are made at King Edward Cove, a sheltered spot on the north-east coast, which does not perhaps represent truly the severity of the climate. In 1953 the average temperature throughout the year was 35.6 degrees $F$. and the extreme minimum recorded was 10 degrees $\mathrm{F}$. in July. Almost certainly the exposed parts of the const, particularly on the south-west side, frequently experience temperatures below zero. Violent winds are common. In 1953 the mean wind-speed was $8 \cdot 9$ knots and precipitation, mostly in the form of snow, amounted to $1,257 \cdot 6 \mathrm{~mm}$. The pattern of the climate of South Georgia is delineated by the relatively low temperatures, the prevailing high winds and the heavy precipitation.

Captain Cook's account of the seals of South Georgia soon attracted attention and in 1790 two American sealers visited the island and obtained part cargoes of fur seal skins. By 1801 the sealing flect at South Georgin numbered thirty-one vessels and the rookeries were being rapidly exhnusted. One vessel alone, the corvette Aspasia, Captain Fanning, took 57,000 skins in that scason. By 1822 Weddell (1825) calculated that not less than 1,200,000 fur scal skins had been shipped from South Georgin and the species was practically extinct there. The rookeries were, in the words of the sealers, "abandoned by the seals" ; more truly, their inhabitants had been exterminated. A few more furs were forthcoming from South Georgin-in 1830 the Elizabeth Jane took 600 and in 1870 the Flying Fish sccured 500. The last considerable catch seems to have been 170 in 1906 (Larsen, 1920) but all this activity was incidental to the 
second phase of exploitation of the seals-elephant oiling. Sea elephants, or elephant scals, provide a valuable oil from their thick investment of blubber. These animals had been generally ignored by the early fur-sealers who were fully occupied with clubbing and skinning the fur seals and were not prepared to spend time flensing and trying out (boiling) elephant blubber. However, as the fur seals declined in number so the sealers turned their attention to the abundant elephant seal rookeries. Few records exist of elephant oiling in South Georgia, but if one is to judge from similar conditions on Heard Island in the Indian Ocean the technique was to put a number of men ashore with stores and equipment for trying out blubber and to leave them there till the casks were full or the sealing ship had to return to her home port. In several of the natural harbours in South Georgia are still to be found the iron pots and brick try-works used by the sealers. The commonest form of try pot, shaped like a traditional witch's cauldron, 3 feet in height and holding about seventy gallons, seems to be of British origin, refuting the generally advanced theory that elephant oiling was a monopoly of the Americans. Indiscriminate slaughter soon reduced the elephants in exactly the same way as it had the fur seals, though as they yiclded a less profitable product, the slaughter was not carried so far. Eventually, by the end of the nineteenth century, South Georgia was visited only by Yankee whalers who hoped to obtain part cargoes of elephant oil and perhaps a few fur skins. The last of these vessels was the brig Daisy of Massachusetts, which visited the island in 1913. On board was Robert Cushman Murphy of the American Museum of Natural History, later to become famous as one of the leading ornithologists of the New World, who published the only well-documented account of the activities of the oldstyle clephant sealing in South Gcorgia (Murphy, 1947).

In the first decade of the present century the modern steam whaling industry of the Antarctic was established in South Georgia by C. A. Larsen. The arrival of the whalers was soon followed by the setting up of a British Administration on the island. At that time fur seals were believed to be extinct but the elephant seals had recovered somewhat from previous depredations and it was realized that rational cropping of the herds would result in a large and continuing return. A series of regulations was laid down designed to ensure the conservation of the elephant seal stock. Killing was to be licensed and restricted to adult males only, reserves were set up and reports on the condition of the rookeries were made yearly. The licence 
to take seals was initially granted to the Compañia Argentina de Pesca, the first whaling company to be established in South Georgia, which has held it ever since. From 1910, when licensing was first introduced, to 1957-227,942 elephant seal bulls have been taken yielding nearly 73,000 tons of oil. These figures do not include the seals taken by the Daisy in 1913-14. The master of this vessel was licensed by the British Magistrate to take bull elephant seals but the conditions of the licence were

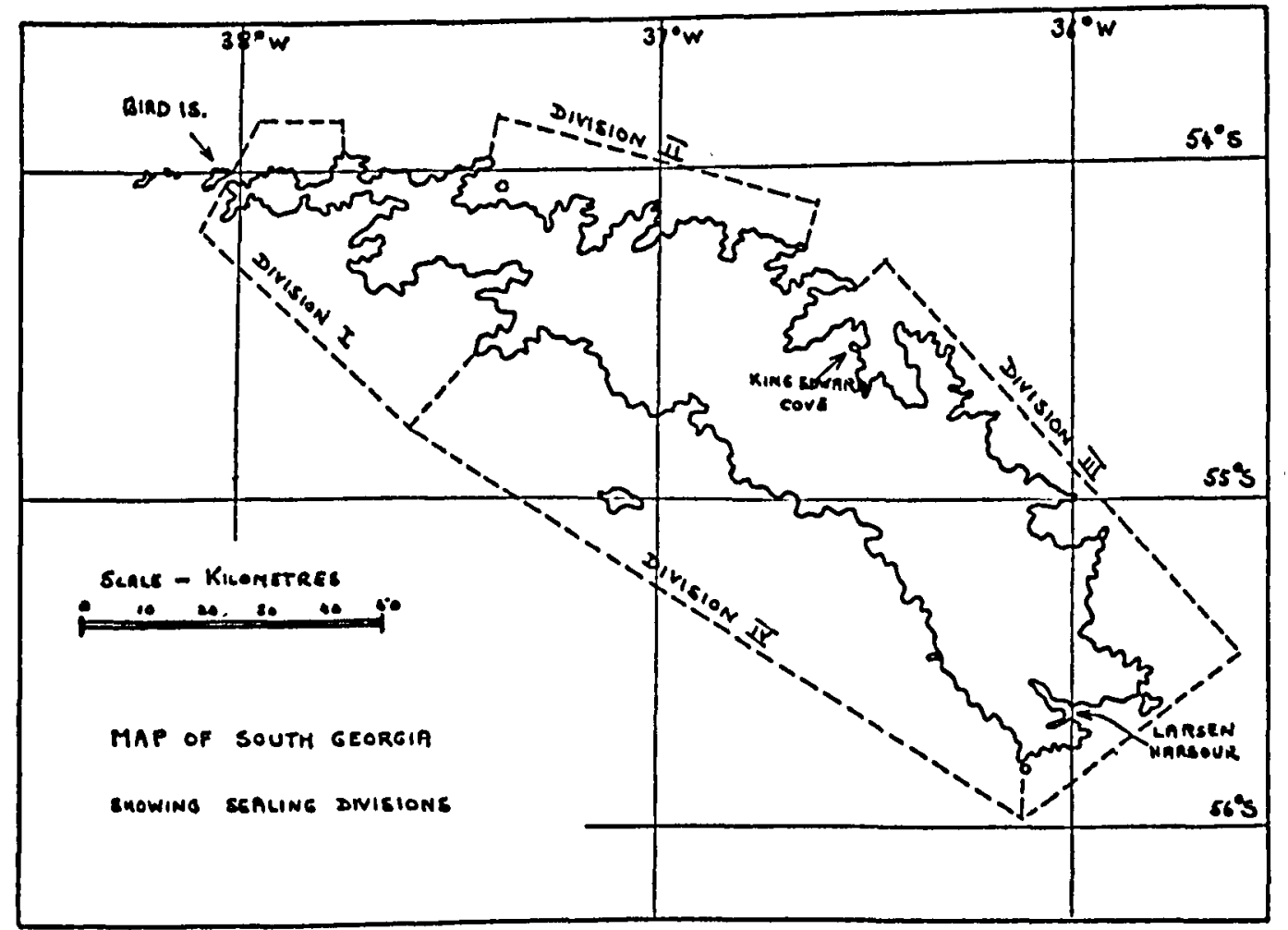

flagrantly ignored. The minimum kill of the Daisy was 1,534 seals ; by 26th January, 1914, 1,094 seals had been taken but "the larger proportion has been made up of cows, and no negligible number have been babies which could be killed only by men capable of crushing the skull of a friendly puppy" (Murphy, 1947). Daisy left South Georgin without making returns of the number of seals killed or the quantity of oil produced from them.

$A$ close season from 1st October to 31st December was originally stipulated in the scaling licence, but this was subsequently extended to 1st March; in 1014 September was also included in the close season as it was noticed that numerous females were seen with young in the latter days of that month. This extended close season hardly allowed the sealers to take their permitted quota of seals and it was later abandoned, sealing 
being permitted from the 1st March to the 31st October. The breeding season of the seals has gradually fallen later in the year, and every season since 1938 the company has successfully applied for an extension of the scason into November. Recently it has been pointed out that the original purpose of the close season, to protect the seals from molestation while breeding, was not being served by allowing killing in November and it has been decided that from 1958 onwards no sealing will be permitted in that month.

The coast of South Georgia is divided for sealing into four Divisions, and two reserves where no sealing is allowed. In addition, sealing is not permitted in one of the large bays of the north-east coast where two whaling companies have their shorestations. Three of the Divisions, which are roughly equal in coastline, are worked each year. The number of scals permitted under the terms of the licence was originally distributed equally between the three Divisions but R. M. Laws, a biologist of the Falklands Islands Dependencies Survey, who worked in South Georgin in 1951-52, drew attention to the fact that the stocks in the different Divisions were by no means equal. Laws carried out a census of the pups born and from these figures calculated the quotas that could be contributed from each of the Divisions in the five years from 1952 to 1956 . At the time that Laws was working in South Georgia one of the Divisions had suffered considerably from over-scaling, but it now appears that this damage has been largely repaired and the position of the stocks in all three Divisions currently gives no cause for alarm. Laws was able to put the conscrvation of the seals on a scientific footing for the first time by his discovery (Laws, 1953) that the age of elephant seals could be determined by examination of the structure of the canine tecth. Cross-sections of the tecth show a scrics of patterns of concentric rings of different types of dentine which correspond to yearly periods in the life of the seal. Sample tecth are now collected from the commercial kill and from these the average age of the seals killed in each Division is worked out. Any increase in the average age of the kill is an indication that the stock is increasing and vice versa. Most of the scals killed to-day are six or seven years old. Seals less than 3.5 metres in nose to tail length are not allowed to be killed, which excludes from the kill scals less than five years old. Few male seals reach an age of over twelve years in South Georgia, though in an undisturbed population such as that at the South Orkney Islands, bulls over twenty years old have been recorded (Laws, 1953). 
The total number of seals permitted to be killed in each year was for a long time fixed at 6,000. In 1948, on the recommendation of the Magistrate at South Georgia, this quota was increased to 7,500. The kill fell off after this but in $\mathbf{1 9 5 1}$ the quota was raised to 8,000 of which only 7,877 seals were actually taken. This was clearly more than the stock would stand and from 1952 to the present date the quota has remained at 6,000 which has been consistently attained till 1957 when only 5,408 seals were secured. This low figure was due to the appalling weather of that season rather than to any lack of seals.

Current sealing practice is to employ three small obsolete - whale catchers each equipped with a motor boat and a pram dinghy which can be hoisted inboard. These vessels operate independently but wireless communications are maintained to ensure that two boats do not visit the same beach in rapid succession. On arrival at the sealing beach the catcher anchors and lowers the boats. The motor boat tows the pram to the shore where the sealing crew lands. One man remains in the pram as it is rarely calm enough to pull the boat ashore. The shore gang consists of a gunner, who shoots the seals and is in charge of the party, a beater, three flensers and three haulers. The gunner selects the seals to be killed and the beater drives them down to the water's edge one by one by striking them lightly about the head with a metal tube some 6 feet long. Skilfully done this causes scarcely any suffering to the seals though the stimulus of receiving repeated blows about the hend, a vulnerable spot, is sufficient to drive even the biggest bulls from their harems. At the water's edge the seals are shot and rapidly divested of their blubber by the flensers assisted by the haulers, who pull the carcase awny from the skin as the flensers cut through the connective tissuc. Next a rope strop is then threaded through the skin which is then towed off-shore by the pram which delivers the skin to the motor bont. The skins float in the water and attract the attention of hundreds of Cape pigeons, Daption capense, which nibble at the blubber. When about six skins have been floated off the motor boat tows them out to the catcher where they are hoisted aboard and stowed in the hold. When one beach has been thoroughly worked the boats return to the catcher which then steams to the next. On making a full cargo, the blubber of about eighty to one hundred and twenty seals, according to the time of the year, the catcher returns to the whaling station where the skins are mineed up mechanically and boiled out. The yield of oil per skin avernges about $\mathbf{2 \cdot 2 8}$ barrels in September when the 
seals first arrive, but drops off to 1.99 barrels by the end of October. It thus pays the sealers to get as much of their quota as possible at the beginning of the season. At the present no use is made of the rest of the carcases of the seals killed, which are left to rot on the beaches after flensing. The wastage of oil and protein is considerable and it is greatly to be hoped that improved methods of operation will permit their use in the near future.

The future of the South Georgia elephant seal herds is assured. The present sealing regulations, with which the sealing company willingly co-operates, are sufficient to ensure the careful control of the stock so necessary for rational harvesting. It even seems probable that the number of elephant seals on South Georgia is greater than ever before.

Besides the elephant seal, Mirounga leonina, three other species of pinnipede breed on South Georgia. These are the leopard seal, IIydrurga leptonyx, the weddell seal, Leptonychotes weddelli, and the fur seal, Arctocephalus gazella, previously erroncously described as $A$. australis, e.g. Matthews 1929, Bonner, 1958. Originally the taking of weddell and leopard seals was allowed under the terms of the licence, but since 1916 weddell seals have been absolutely protected and no leopard scals have appeared on the returns since 1927. Weddell seals have never been numerous in South Georgia; there is a small breeding colony at the south-east end of the island in Larsen Harbour which produced twenty-six pups in 1056 and twentyseven the following season. In 1914 about thirty seals altogether were seen at this colony so it seems to have expanded slightly. These animals are worthy of protection as they represent the extreme northern brecding limit of the species, which is more typically found near the pack ice. Leopard seals are the only species of pinnipede in the Falkland Islands Dependencies which are afforded no measure of protection. 'This is probably due to their habit of preying on those favourite birds, penguins; $\Omega$ leopard seal nearly always being found in the waters off penguin rookcries. It was stated in 1929 that "the sea-lcopard ... is a ferocious pest, which preys on penguins as well as fish, and any diminution in its numbers may, perhaps, be viewed with equanimity". As Harrison Matthews (1029) pointed out, no reasons are given for preferring fish and penguins to leopard scals. Some few leopard seals are shot each year, mostly in the winter, by the whalers who covet their beautifully marked skins. In many cases the preparation of the pelt is too much trouble for the hunter and the animals are killed in vain. The main 
headquarters of the species is further south, the South Georgia population consisting mainly of winter migrants. Being a solitary animal that spends most of its time in the water the leopard seal is relatively inaccessible to molestation and protective measures are perhaps unnecessary.

In recent years fur seals have been seen again round the coasts of South Georgia. Rankin (1951) reported about twenty ashore in 1946-47 and the present author encountered several in the summer of 1953-54. In December, 1950, I was able, by the courtesy of the manager of the sealing company, to visit Bird Island at the extreme north-west end of South Georgia. Here a large colony of fur seals was established. Owing to lack of time only a rough count of pups could be made; this amounted to 3,250 , from which a total population of between 8,000 and 12,000 animals excluding pups was calculated (Bonner, 1958). In 1957 another visit was made to the colony and a much more accurate count revealed 4,500 pups. These figures are not strictly comparable, owing to different methods used, but it is believed that some at least of the apparent increase is real. The total population calculated from 4,500 pups amounts to about 15,000 animals. So far no exploitation of this potentially exceedingly valuable resource is contemplated. Some animals are being killed to obtain the scientific information so necessary for the firm biological background without which no conservation programme can hope to be a success and it is considered essential to obtain this information before any licence to kill is granted. It is hoped that the fur seals will spread from Bird Island to the mainland and repopulate the old rookeries that were exterminated in the nineteenth ecntury but there are difficulties in the way of this. Female fur seals are gregarious and will not haul out to have their pups alone. The minimum group of cows to form a stable unit in the nearly allied northern fur seal, Callorhinus ursinus, is three or four (Bnrtholomew, 1953), thus simultaneous colonization by at least that number and a bull is required to initiate another rookery. It is possible, also, that the elephant seals, which the fur seals tolernte rather badly, have appropriated some of the old fur seal haunts. Nevertheless, it is expected that colonization will take place in the not too distant future and it may even be possible to expedite this by penning pregnant cows on suitable sites on the mainland until their pups are born.

The carly history of scaling in South Georgia has been of uncontrolled exploitation leading to the near-extermination of the animals concerned. By judicious use of control measures 
the remnant stock of elephant seals has recovered to provide a yearly harvest of edible oil, worth at current prices about $£ 150,000$. Moreover, it now appears that the fur seal stock is building up and in the course of the next decade or so will provide its quota to the resources of an island which, with the decline of the whaling industry, are severely limited.

\section{REFERENCES}

1020. Report of the Interdepartmental Committec for Research and Development in the Dependencies of the Falkland Islands. London : H.M.S.O.

BARtiolonisw, G. A., 1953. Behavioural factors affecting social structure in the Alaska fur seal. Proc. N. Amer. Wildl. Conf., 18, 481-502.

Bonnen, IV. N., 1058. Notes on the southern fur seal in South Georgia. Proc. zool. Soc. Lond., 130, 241-252.

LAnsen, C. A., 1020. In loc. cit., 1020 supra.

LAwS, R. MI.; 1053a. $A$ new method of nge determination in mammals with special reference to the elephant seal (MIirounga leonina Linn.). Falklands Islands Dependencies Survey Scientific Reports, No. 2. 11 pp.

1053b. The elephant seal (Mirounga leonina Linn.). I, Growth and age. FalkIands Islands Dependencies Survey Scientific Reports, No. 8. $62 \mathrm{pp}$. Matrinews, L. H., 1029. The natural history of the elephant seal. Discovery Rep., $1,233-250$.

Munpiry, R. C., 1047. Logbook for Grace. New York.

Rankin, N., 1051. Antarctic Isle. London.

Wropers, J., 1825. A Voyage Tozvards the South Pole. London. 


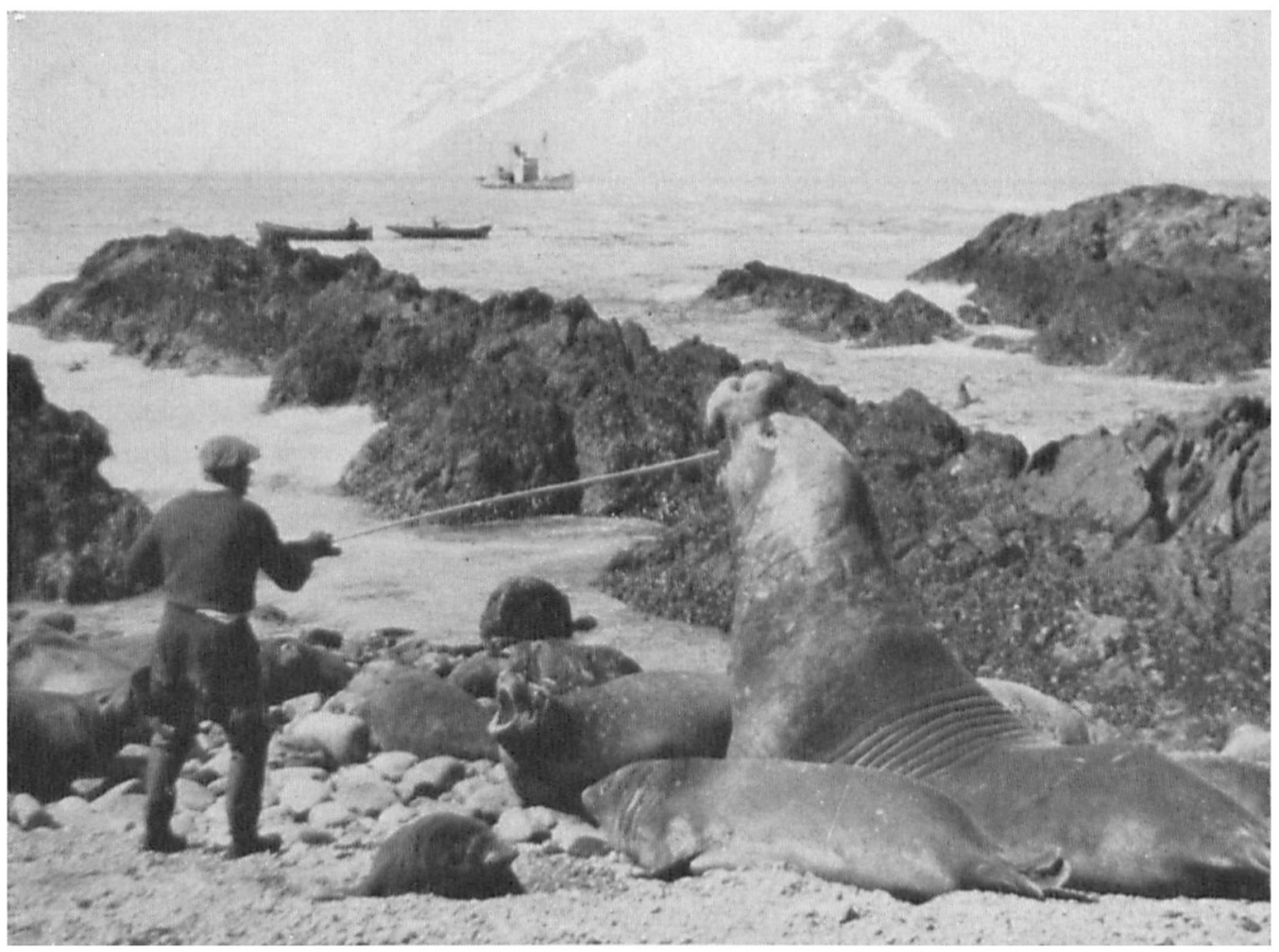

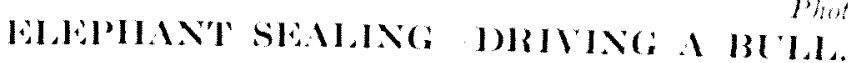

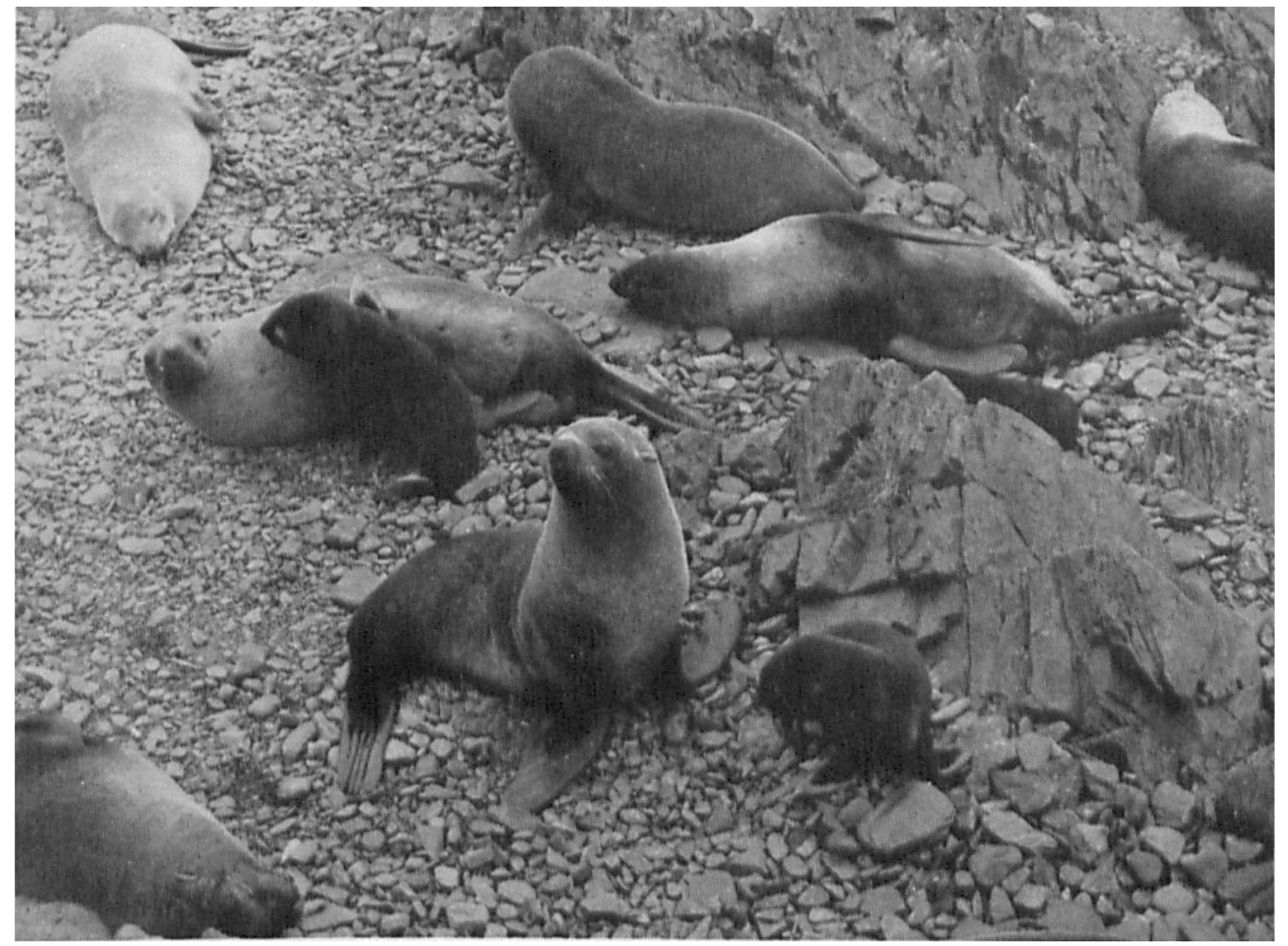

Theto: W. X. Dimner

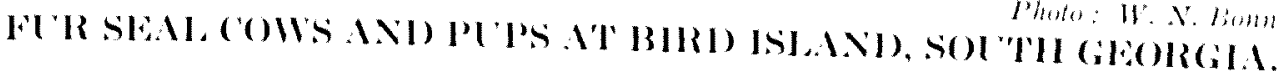

